\title{
Copper(II) Removal from Aqueous Solutions by Adsorption Method: Isothermal, Thermodynamic and Kinetic Studies
}

\author{
Bakır(II) İyonlarının Sulu Ortamdan Adsorpsiyon Yöntemiyle \\ Uzaklaştırılması: İzotermal, Termodinamik ve Kinetik Çalışmalar
}

Research Article

Ali Kara* and Sevgi Sözügeçer

Uludağ University, Faculty of Science and Arts, Chemistry Department, Bursa, Turkey.

\section{A B S T R AC T}

tudy presents the utility of magnetic poly(ethyleneglycoldimethacrylate- $N$-vinyl-2-pyrrolidone) [m-p(EG$\checkmark$ VPN)] microspheres as an adsorbent for copper(II) ion removal from aqueous solutions. The magnetic polymer microspheres were characterized by elemental analysis, $\mathrm{N}_{2}$ adsorption-desorption isotherm tests, swelling studies, scanning electron microscope (SEM) and vibrating sample magnetometer (VSM). Adsorption studies revealed that the maximum adsorption capacity of $\mathrm{m}-\mathrm{p}(\mathrm{EG}-\mathrm{VPN}) \mathrm{microspheres}$ was $270.3 \mathrm{mg} / \mathrm{g}$. Besides, kinetic, isothermal and thermodynamic properties of the adsorption were also investigated.

\section{Key Words}

$\mathrm{Cu}(\mathrm{II})$ removal, adsorption kinetics, adsorption thermodynamics, $\mathrm{Cu}(\mathrm{II})$ ions.

\section{Ö z}

\begin{abstract}
alışmada, manyetik poli(etilenglikoldimetakrilat-N-vinil-2-pirolidon) [m-p(EG-VPN)] mikrokürelerinin bakır (II) iyonlarının sulu ortamdan uzaklaştırılmasında adsorbent olarak kullanılabilirliği incelenmiştir. Manyetik polimer mikroküreler, elementel analiz, $\mathrm{N}_{2}$ adsorpsiyon-desorpsiyon izoterm testleri, şişme testleri, taramalı elektron mikroskobu (SEM), titreşimli örnek manyetometresi (VSM) ile karakterize edilmiştir. Adsorpsiyon çalışmaları sonucunda m-p(EG-VPN) mikrokürelerinin maksimum adsorpsiyon kapasitesi $270.3 \mathrm{mg} / \mathrm{g}$ olarak belirlenmiştir. Ayrıca adsorpsiyon işlemlerinin kinetik, izotermal ve termodinamik özellikleri araştırılmıştır.
\end{abstract}

\section{Anahtar Kelimeler}

Bakır(II) uzaklaştırma, adsorpsiyon kinetiği, adsorpsiyon termodinamiği, Cu(II) iyonu.

Article History: Received: Mar 11, 2017; Revised: Aug 15, 2017; Accepted: Oct 25, 2017; Available Online: Dec 25, 2017. DOI: 10.15671/HJBC.2017.170

Correspondence to: A. Kara, Uludag University, Faculty of Science and Arts, Chemistry Department, Bursa, Turkey. 


\section{INTRODUCTION}

E nvironmental pollution is one of the main - problem of expanding industrialization. Water contamination from industrial waste is an increasing case with each passing day. Since heavy metals can accumulate in human body, heavy metal content of water may have a great potential to be very hazardous to human health and natural life [1-3]. Copper(II) is an essential nutritional source such as zinc, manganese, iron, boron molybdenium, chlorine. Nevertheless, it should be limited at between 5-20 ppm since it's inadequate under $5 \mathrm{ppm}$ and toxic at concentrations higher than 20 ppm. High copper(II) levels in aqueous media in nature may cause copper(II) poisoning which may end up with coma and death. So that World Health Organization (WHO) reported that maximum levels of copper(II) concentration should be $1.5 \mathrm{ppm}$ [4-5]. Adsorption is the most common selection among all methods for heavy metal removal. Adsorbent is the key factor which identifies the adsorption capacity. Future applications of adsorption arelimited bygeneration of new and better adsorbents to improve the performance of current commercial processes as the adsorbent should be designed for the needs of specific applications [6]. In order to design an adsorbent for heavy metal removal, stability for the selective removal of metal ions, specific and fast complexation is of great importance [7]. Using chelating polymers to having features as mentioned above for heavy metal removal is widespread in environmental applications [8]. Number of chelating polymers have been produced by chelating monomers, such as acrylic acid, allythiourea, vinyl imidazole and vinyl pyrrolidone [9]. Magnetic material attachment to the chelating polymers enhance the properties of an adsorbent by means of diffusion ressistance, adsorption capacity, fast separation for large volumes $[10,11]$. Determination of physicochemical parameters of adsorption allows of understanding the adsorption mechanism, surface properties, degree of affinity of the adsorbents and provide applicable practice of adsorption systems [12] This paper presents kinetic, thermodynamic and isothermal investigation of $\mathrm{Cu}(\mathrm{II})$ adsorption onto magnetic(ethylene glycol dimethacrylate- $\mathrm{N}$ vinyl-2-pyrrolidone) microspheres.

\section{MATERIALS and METHODS}

\section{Materials}

Ethylene glycole dimethacrylate (EGDMA), poly(vinyl alcohol) (Mw: 72.000, 98\% hydrolyzed), 2,2'-azobisisobutyronitrile (AIBN), sodiumhydroxide $(\mathrm{NaOH})$ and nitric acid $\left(\mathrm{HNO}_{3}\right)$ (Merck, Darmstadt, Germany), 1,2-N-vinylpyrrolidone (VPN) (Aldrich, Steinheim, Germany), magnetite $\left(\mathrm{Fe}_{3} \mathrm{O}_{4}\right.$; diameter 20-30 nm, Aldrich, USA), copper(II) nitrate trihydrate $\left(\mathrm{Cu}\left(\mathrm{NO}_{3}\right)_{2} 3 \mathrm{H}_{2} \mathrm{O}\right)$ (Carlo Erba Reagent). All other reagents were of analytical grade and were used without further purification.

\section{Synthesis of the m-p(EG-VPN) Microspheres}

$M-p(E G-V P N)$ microspheres was prepared by suspension polymerization. Procedure is as follows: In order to obtain suspemsion aqueous and organic phases are set. Aqueous phase consists of $0.2 \mathrm{~g}$ PVA as a stabilizer and $50.0 \mathrm{~mL}$ distilled water. Organic phase contains $0.1 \mathrm{~g}$ AIBN as initiator, $10.0 \mathrm{~mL}$ toluene as a pore former, 5.0 $\mathrm{mL}$ EGDMA as a crosslinker and $3.4 \mathrm{~mL}$ VPN as a monomer. At first, PVA was dissolved in water and put into sealed-cylindrical pyrex polymerization reactor temperature stated at $65^{\circ} \mathrm{C}$. Secondly, magnetite was added to the aqueous phase. Then, organic phase containing monomer, crosslinker, initiator and pore former was added to the reaction mixture by stirring it with magnetic stirrer for $4 \mathrm{~h}$ at stated temperature. Afterwards, polymerization temperature was set to $75^{\circ} \mathrm{C}$ and the reaction was proceeded for $2 \mathrm{~h}$ at $600 \mathrm{rpm}$ stirring rate (Schema 1). Synthesised microspheres were kept waiting in ethanol/water mixture for a day. Then by decantation of liquid mixture, polymer microspheres washed with ethanol and water in order to remove unreacted monomer or diluent and dried in a vacuum oven at $70^{\circ} \mathrm{C}$. Dried microspheres then sieved to 53-512 $\mu \mathrm{m}$ size range by using sieve set (AS200, Retsch Gmb \& Co., KG, Haan, Germany).

\section{Characterization of the $m-p(E G-V P N)$ Microspheres \\ Morphological Properties of $m-p(E G-V P N)$ Microspheres}

Morphological properties of m-p(EG-VPN) microspheres, which were sieved and 53-212 $\mu \mathrm{m}$ size-ranged, were examined by scanning electron microscopy (SEM, Carl Zeiss Evo 40, Cambridge, 

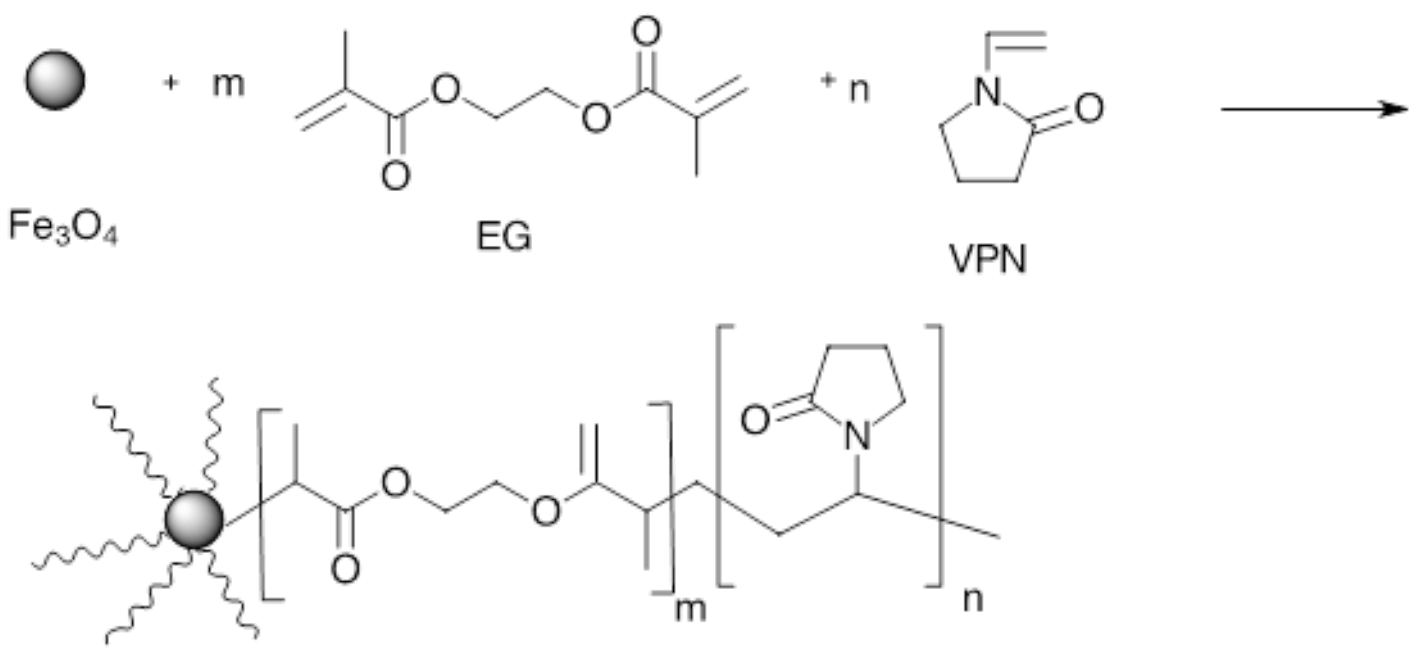

\section{$m-p(E G-V P N)$}

Schema 1. Schematic illustration of polymerization of EG and VPN with the presence of magnetite.

UK).The porosity of the size-ranged microspheres was determined by $\mathrm{N}_{2}$ gas adsorption/desorption isotherm technique (Quantachrome, Poremaster 60, USA). The specific surface area of microsperes in a dry state, was determined by a multipoint Brunauer-Emmett-Teller (BET) apparatus (Quantachrome, Autosorb-6, USA). BJH model (Barret, Joyner, Halenda) was applied in order to determine the pore volumes and avarage pore diameter of polymer microspheres.

\section{Swelling Tests}

$1.023 \mathrm{~g}$ dry m-p(EG-VPN) microsphere sample was immersed in $50 \mathrm{~mL}$ of distilled water in $100 \mathrm{~mL}$ glass bottle placed in a isothermal water bath at $25^{\circ} \mathrm{C}$ and kept waiting for $2 \mathrm{~h}$. Sample was filtrated and weighed. The percentage of swelling was determined by the following formula:

swelling ratio=(weight of swollen sample-weight of dry sample)/(weight of dry sample) x100

\section{Elemental Analysis}

Monomer incorporation to $m-p(E G-V P N)$ microspheres were identified with elemental analysis (Leco Elemental Analyser, CHNS-932,USA).

\section{Adsorption Experiments}

Batch adsorption experiments carried out with $m-p(E G-V P N)$ microspheres and aqueous $\mathrm{Cu}(\mathrm{II})$ solutions. Concentration of every solution was $1000 \mathrm{mg} / \mathrm{L}$ since the spectrophotometric analysis indicated that it was the most appropriate concentration as a stock solution. In order to obtain desired concentrations, every solution was prepared by diluting the solution. However, concentration studies were carried out with more concentrated solutions. pH was adjusted by using $\mathrm{NaOH}$ and $\mathrm{HNO}_{3}$ solutions.

Adsorption processes were as follows: $50 \mathrm{mg}$ $m-p(E G-V P N)$ microspheres were added to 50 $\mathrm{mL} \mathrm{Cu(II)} \mathrm{solutions} \mathrm{in} 100 \mathrm{~mL}$ erlenmayer flasks and kept waited for $2 \mathrm{~h}$ and filtered. The filtrate and the initial solution were analysed by using UV-vis spectrophotometer (Shimadzu-2100 UVvis, Japan), was used as a complexing agent. The amount of adsorbed $\mathrm{Cu}(\mathrm{II})$ ions calculated from difference between initial and the filtrate concentration.

\section{Desorption and Repeated Ese Experiments}

$\mathrm{Cu}(\mathrm{II})$ attached $\mathrm{m}-\mathrm{p}(\mathrm{EG}-\mathrm{VPN})$ microspheres desorbed in $0.2 \mathrm{M} \mathrm{M} \mathrm{NaOH}$ solution [7] in a shaking water bath at $300 \mathrm{rpm}$ for $24 \mathrm{~h}$ at room temperature. The desorption ratio was calculated according to the following expression:

Desorption ratio $=($ Amount of desorbed $\mathrm{Cu}(\mathrm{II})$ ions to the desorption medium)/(Amount of $\mathrm{CU}$ (II) ions adsorbed onto $m-p(E G-V P N)) \times 100$ 


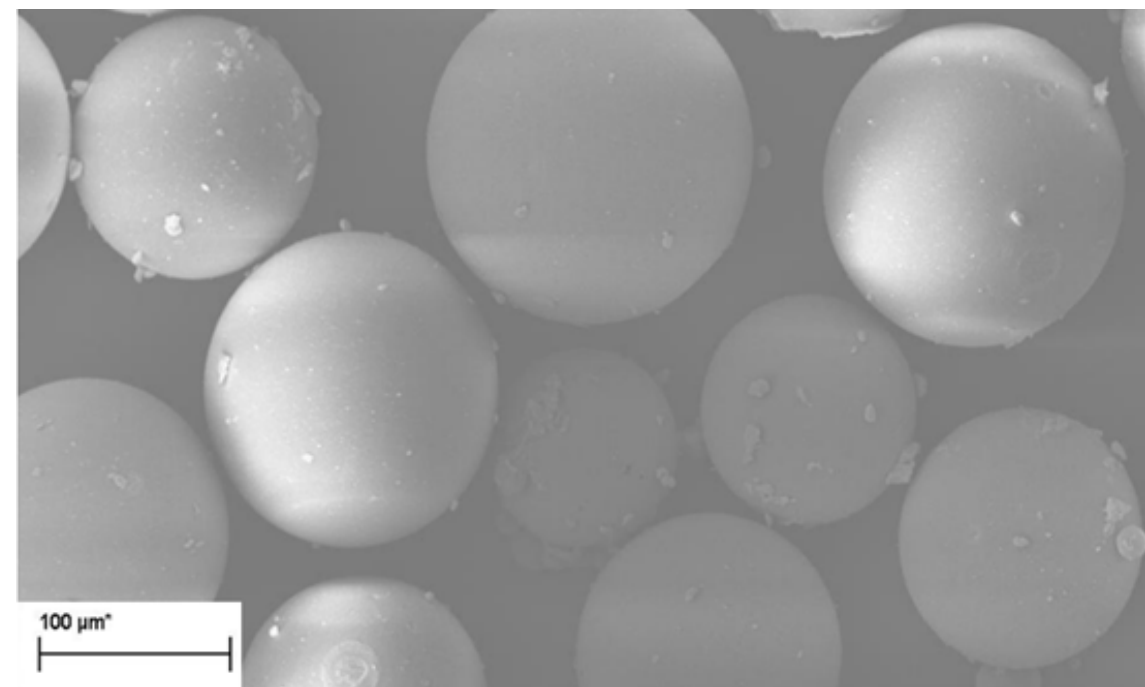

Figure 1. Schematic illustration of polymerization of EG and VPN with the presence of magnetite.

Table 1. Surface area, pore size range and total pore volüme range of $m-p(E G-V P N)$ microspheres.

\begin{tabular}{ccc}
\hline BET Surface Area & BJH Pore Size Range & Total Pore Volume Range \\
\hline $140.7 \mathrm{~m}^{2} / \mathrm{g}$ & $1.650-9.464 \mathrm{~nm}$ & $0.07124-0.6335 \mathrm{~cm}^{3} / \mathrm{g}$ \\
\hline
\end{tabular}

Table 2. Elemental analysis results of $m-p(E G-V P N)$ microspheres.

\begin{tabular}{ccc}
\hline$\% \mathrm{C}$ & $\% \mathrm{H}$ & $\% \mathrm{~N}$ \\
\hline 54.71 & 7.54 & 3.77 \\
\hline
\end{tabular}

Reusibility of m-poly(EGDMA-VPN) microspheres were investigated by repeating adsorptiondesorption cycles for ten times by using the same magnetic polymer microspheres.

\section{RESULTS and DISCUSSION}

\section{Morphological Properties of m-p(EG-VPN) Microspheres}

Scaning electron microscope image of $m-p(E G-$ VPN) microspheres can be seen in Figure 3. The image clearly demonstrated the spherical shape of $m-p(E G-V P N)$ adsorbent

According to the calculations of $\mathrm{N}^{2}$ adsorption/ desorption isotherm tests, the BET surface area was $140.7 \mathrm{~m}^{2} / \mathrm{g}$, BJH pore size range was $1.650-9.464 \mathrm{~nm}$, total pore volume range was $0.07124-0.6335 \mathrm{~cm}^{3} / \mathrm{g}$ (Tables 1 and 2). These results indicated that the $m-p(E G-V P N)$ microspheres were mainly mesopores. M-p(EGVPN) microspheres have large pores that make the adsorbent have better diffusion properties.
All these features may increase the binding capacity onto m-p(EG-VPN) microspheres and mass transfer rate of $\mathrm{Cu}(\mathrm{II})$ ions [18].

\section{Magnetic Properties of $m-p(E G-V P N)$ Microspheres}

Magnetic properties of polymer microspheres was determined by using VSM technique. As it can be driven from VSM spectrum, Figure 3, saturation magnetization value, $M_{s^{\prime}} 9.08 \mathrm{emu} / \mathrm{g}$, magnetic coercive field, $\mathrm{H}_{\mathrm{c}^{\prime}} \mathrm{0}, 0118 \mathrm{~T}$, magnetic remanence, $M_{r^{\prime}} 1.06 \mathrm{emu} / \mathrm{g}$ and polymer microspheres were soft magnetic material. Since magnetite was superparamagnetic material, synthesized microspheres being soft magnetic proved that magnetite particles were contributed the polymer structure.

\section{Analysis of Adsorption Isotherms}

Data of the effect of initial concentration of $\mathrm{Cu}(\mathrm{II})$ adsorption onto m-p(EG-VPN) microspheres investigation used to evaluate adsorption isotherms: Langmuir and Freundlich isotherm models. 


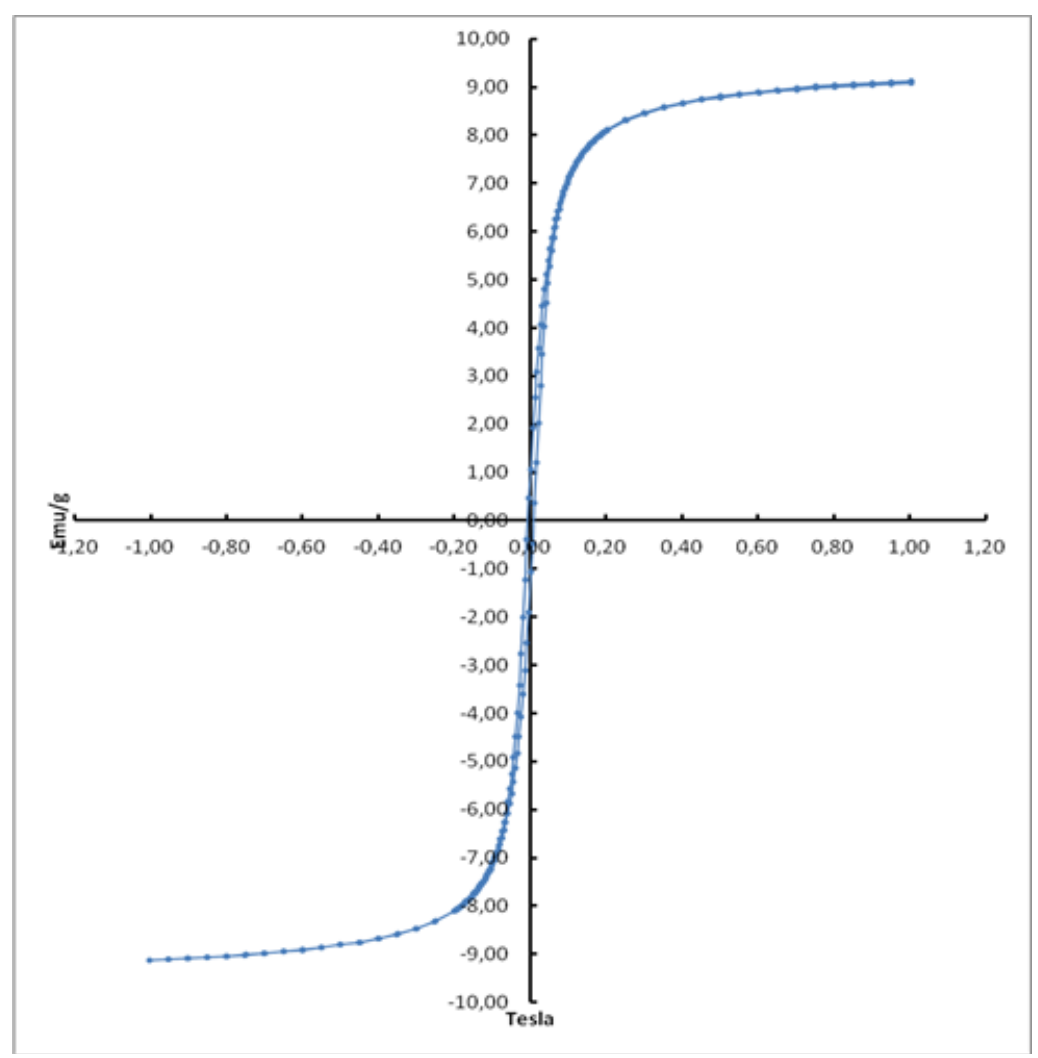

Figure 3. VSM spectrum of m-poly(EGDMA-VPN) microspheres.

The Langmuir isotherm expression is as follows [13]:

$C_{e} / q_{e}=1 /\left(Q_{L} K_{L}\right)+C_{e} / Q_{L}$

where $Q_{L}(\mathrm{mg} / \mathrm{g})$ is the maximum amount of $\mathrm{Cu}(\mathrm{II})$ ion adsorbed onto per unit weight of $m-p$ (EGVPN) microspheres to form complete monolayer coverage on the surface and also represents a particle limiting adsorption capacity when the adsorbent surface is fully covered with $\mathrm{Cu}(\mathrm{II})$ ion, $Q_{e}$ is the amount of $\mathrm{Cu}(\mathrm{II})$ ion at equilibrium time $(\mathrm{mg} / \mathrm{g}), C_{e}(\mathrm{mg} / \mathrm{L})$ is equilibrium concentration, $K_{L}(1 / \mathrm{mg})$ is Langmuir constant related to affinity of binding sites. $Q_{L}$ and $K_{L}$ values of $\mathrm{Cu}(\mathrm{II})$ adsorption were calculated from the slopes and intercepts of plot of $C_{e} / Q_{e}$ versus $C_{e}$ and given in Table 3. The linearized form of Freundlich isotherm equation [14]:

$$
\ln q_{e}=\ln K_{f}+\frac{1}{n} \ln C_{e}
$$

In this equation, $Q_{e}$ and $C_{e}$ have the same definitions with Langmuir isotherm model, $\mathrm{K}_{\mathrm{f}^{\prime}}$ $1 / n$ and $n$ are isotherm constants indicates the capacity and intensity of adsorption, respectively. The values of $\mathrm{Kf}$ and $\mathrm{n}$ calculated from the slope and the intercept of the plot $\ln Q_{e}$ versus $\ln C e$. Obtained values are demonstrated in Table 3.

In addition to Langmuir and Freundlich isotherm models, in order to have a detailed information about adsorption mechanism, Dubinin Radushkhevich isotherm ( $D-R$ isotherm) model was prefered as this model predicts the nature of adsorbate sorption onto the adsorbent and also it is possible to calculate the mean free energy of adsorption. The non-linear $D-R$ isotherm expression:

$Q_{e}=Q_{D-R} \exp \left(-K_{D-R} \varepsilon^{2}\right)$

And the linearized form of this equation is:

$$
\ln Q_{e}=\ln Q_{D-R}-K_{D-R} \varepsilon^{2}
$$


Table 3. Parameters of Langmuir, Freundlich and Dubinin Raduskhevich isotherm models for Cu(II) adsorption onto mp(EG-VPN) microspheres.

\begin{tabular}{|c|c|c|c|c|c|c|c|}
\hline \multirow{2}{*}{$\begin{array}{c}\text { Temperature } \\
(\mathrm{K})\end{array}$} & \multicolumn{4}{|c|}{ Langmuir isotherm constants } & \multicolumn{3}{|c|}{ Freundlich isotherm constants } \\
\hline & $\begin{array}{c}K_{L} \times 10^{3}(\mathrm{~L} / \\
\mathrm{mg})\end{array}$ & $Q_{L}(\mathrm{mg} / \mathrm{g})$ & $R^{2}$ & $\mathrm{R}_{\mathrm{L}}$ & $\mathrm{K}_{\mathrm{F}}$ & $\mathrm{n}$ & $\mathrm{R}^{2}$ \\
\hline 277 & 1.089 & 204.1 & 0.9906 & $\begin{array}{l}0.155^{-} \\
0.902\end{array}$ & 1.833 & 1.780 & 0.9529 \\
\hline 298 & 1.394 & 270.3 & 0.9930 & $\begin{array}{l}0.125- \\
0.878\end{array}$ & 5.213 & 2.127 & 0.9763 \\
\hline 318 & 1.461 & 277.8 & 0.9920 & $\begin{array}{l}0.120- \\
0.873\end{array}$ & 5.368 & 2.121 & 0.9734 \\
\hline 338 & 1.501 & 285.7 & 0.9912 & $0.118-0.869$ & 6.123 & 2.183 & 0.9739 \\
\hline \multicolumn{8}{|c|}{ Dubinin-Raduskhevich isotherm constants } \\
\hline $\begin{array}{c}\text { Temperature } \\
(\mathrm{K})\end{array}$ & \multicolumn{3}{|c|}{$K_{D-R} \times 10^{9}\left(\mathrm{~mol}^{2} / \mathrm{J}^{2}\right)$} & \multicolumn{2}{|c|}{$\mathrm{E}(\mathrm{kJ} / \mathrm{mol})$} & \multicolumn{2}{|c|}{$\mathrm{R}^{2}$} \\
\hline 277 & \multicolumn{3}{|c|}{-12.72} & \multicolumn{2}{|c|}{6.269} & \multicolumn{2}{|c|}{0.9890} \\
\hline 298 & \multicolumn{3}{|c|}{-9.516} & \multicolumn{2}{|c|}{7.662} & \multicolumn{2}{|c|}{0.9904} \\
\hline 318 & \multicolumn{3}{|c|}{-8.407} & \multicolumn{2}{|c|}{7.712} & \multicolumn{2}{|c|}{0.9866} \\
\hline 338 & \multicolumn{3}{|c|}{-6.645} & \multicolumn{2}{|c|}{8.874} & \multicolumn{2}{|c|}{0.9860} \\
\hline
\end{tabular}

Table 4. Parameters that indicate the adsorption is favorable.

\begin{tabular}{ccccc}
\hline $\mathrm{R}_{\mathrm{L}}$ Values & $\mathrm{R}_{\mathrm{L}}>1$ & $\mathrm{R}_{\mathrm{L}}=1$ & $0<\mathrm{R}_{\mathrm{L}}<1$ & $\mathrm{R}_{\mathrm{L}}=0$ \\
\hline Isotherm Type & Unfavorable & Linear & Favorable & Irreversible \\
\hline
\end{tabular}

where Qe has the same definition with Langmuir isotherm model, $Q_{D-R}$ is the maximum adsorption capacity $(\mathrm{mg} / \mathrm{g}), K_{D-R}$ is the D-R constant $\left(\mathrm{mol}^{2} / \mathrm{J}^{2}\right)$, $\varepsilon$ is Polanyi potential $(\mathrm{J} / \mathrm{mol})$. This potential can be calculated from the following equation:

$$
\varepsilon=R T\left[\ln \left(1+\frac{1}{C_{e}}\right)\right]
$$

$R$ is the gas constant $(\mathrm{J} / \mathrm{mol} \mathrm{K}), T$ is the absolute temperature $(K)$ and $C_{e}$ has the same definition with the Langmuir isotherm model. The mean free energy of adsorption $\left(\mathrm{E}_{\mathrm{fe}}\right)$ was calculated from the following equation $[15,16]$ :

$$
E_{f e}=1 / \sqrt{-2 K_{D-R}}
$$

All the calculated parameters of all adsorption isotherm models are shown in Table 1.
Langmuir isotherm fits better with the experimental data correlation coefficient and calculated maximum adsorption capacities are close to maximum capacities obtained at equilibrium compare to other isotherm models. This case can be explained as there is homogeneous distribution of active sites on the surface of $m-p(E G-V P N)$ microspheres since the Langmuir equation assumes that the surface is homogeneous.

Besides, the characteristic of the Langmuir isotherm can be expressed by a dimensionless separation factor $\left(R_{\mathrm{L}}\right)[17]$ :

$$
R_{L}=\frac{1}{1+K_{L} C_{e}}
$$

Based on Table 4, we may say $R_{L}$ values indicates $\mathrm{Cu}(\mathrm{II})$ adsorption onto $\mathrm{m}-\mathrm{p}(\mathrm{EG}-\mathrm{VPN})$ microspheres is favorable. 
$\mathrm{E}_{\mathrm{fe}}$ value of adsorption ascertains the type of adsorption process. If the value is between 8-16 $\mathrm{kJ} / \mathrm{mol}$, it's said that the adsorption type is chemical adsorption. Values lower than $8 \mathrm{~kJ} /$ mol indicate that adsorption type is physical adsorption [18-20]. In this case, we can assume that the adsorption process is physical in nature at 277 and $298 \mathrm{~K}$.

\section{Thermodynamic Analysis of Adsorption}

By using the van't Hoff equation, thermodynamic parameters of adsorption can be evaluated. The integrated form of the equation is as follows:

$$
\ln K_{L}=\frac{\Delta S^{0}}{R}-\frac{\Delta H^{0}}{R} \cdot \frac{1}{T}
$$

The standard enthalpy and entropy changes of an adsorption process can be determined from the slope and intercept of the line obtained by plotting In $K_{L}$ versus $1 / T$. Gibbs free energy of the adsorption process was determined by the following equation:

$$
\Delta G^{\circ}=\Delta H^{\circ}-T \Delta S^{\circ}
$$

Table 5. Thermodynamic parameters of $\mathrm{Cu}(\mathrm{II})$ adsorption

\begin{tabular}{|c|c|c|}
\hline $\begin{array}{c}\Delta G^{\circ}(\mathrm{kJ} / \mathrm{mol}) \text { at } \\
298 \mathrm{~K}\end{array}$ & $\Delta \mathrm{H}^{\circ}(\mathrm{kJ} / \mathrm{mol})$ & $\Delta \mathrm{S}^{\circ}(\mathrm{J} / \mathrm{mol} \mathrm{K})$ \\
\hline-11.11 & 3.992 & 50.06 \\
\hline
\end{tabular}
onto $m-p(E G-V P N)$.

Negative value of Gibbs free energy change indicated that the adsorption process was thermodynamically feasable and spontaneous (Table 5). The standard enthalpy change of the adsorption was related to process being endothermic in nature. Since standard entropy change value is low, we may say there was no remarkable entropy change [21].

\section{Analysis of Adsorption Kinetics}

In order to determine the mechanism of adsorption, Pseudo-first order kinetic model, Pseudo-second order kinetic model, Ritchie'ssecond order kinetic model and intraparticle diffusion model were investigated at $400 \mathrm{mg} / \mathrm{g}$ initial concentration, $\mathrm{pH}: 6.5$, at four different temperatures $(277,298,318$ and $338 \mathrm{~K})$.
The pseudo-first order kinetic model, Lagergren equation is as follows [22]:

$$
\log \left(q_{e}-q_{t}\right)=\log q_{e}-\frac{k_{1}}{2.303} t
$$

Where $Q_{e}(\mathrm{mg} / \mathrm{g})$ is the amount of adsorbed $\mathrm{Hg}$ (II) ions onto m-p(EG-VPN) microspheres at equilibrium, $q_{t}(\mathrm{mg} / \mathrm{g})$ is the amount of adsorbed $\mathrm{Hg}(\mathrm{II})$ ions onto $\mathrm{m}-\mathrm{p}$ (EG-VPN) microspheres at time (min) and $k 1(1 / \mathrm{min})$ is the rate constant of Pseudo-first order adsorption.

The pseudo-second order kinetic model, Ho equation is as follows [23]:

$$
\frac{t}{q_{t}}=\frac{1}{k_{2} q_{e}^{2}}+\frac{1}{q_{e}} t
$$

Where $Q_{e}$ and qt have the same definitions with the pseudo-first order kinetic model and $k_{2}(\mathrm{~g} /$ mg.min) is the rate constant of Pseudo-second order adsorption.

The initial adsorbent rate ( $h, \mathrm{mg} / \mathrm{g} . \mathrm{min}$ ) equation is given below:

$$
h=k_{2} q_{e}^{2}
$$

Ritchie's second order kinetic model expression is [24]:

$$
\frac{1}{q_{t}}=\frac{1}{k_{R} q_{e} t}+\frac{1}{q_{e}}
$$

Where $Q_{e}$ and qt have the same definitions with the Pseudo-first order kinetic model and $k_{R}(1 /$ $\min$ ) is the rate constant.

The intraparticle diffusion model expression is [25]:

$$
q_{t}=k_{i} t^{1 / 2}
$$

Where $q_{t}(\mathrm{mg} / \mathrm{g})$ have the same definitions with the Pseudo-first order kinetic model and $\mathrm{ki}$ $(\mathrm{mg} / \mathrm{min} 1 / 2)$ is the intraparticle diffusion rate.

In order to determine the mechanism of adsorption, pseudo-first order kinetic model, pseudo-second order kinetic model at four different temperatures $(277,298,318$ and $338 \mathrm{~K})$ and results were given in Table 6. 
Table 6. Kinetic parameters for the $\mathrm{Cu}(\mathrm{II})$ adsorption onto m-p(EG-VPN) microspheres.

\begin{tabular}{|c|c|c|c|c|c|}
\hline \multicolumn{6}{|c|}{ Pseudo First Order Kinetic Model } \\
\hline $\begin{array}{c}\text { Temperature } \\
(\mathrm{K})\end{array}$ & $\begin{array}{c}\text { Experimental } \\
\text { Qe }(\mathrm{mg} / \mathrm{g})\end{array}$ & $\begin{array}{l}\mathrm{k}_{1} \times 10^{-2} \\
(1 / \mathrm{min})\end{array}$ & $\begin{array}{c}Q_{e} \\
(\mathrm{mg} / \mathrm{g})\end{array}$ & & $\mathrm{R}^{2}$ \\
\hline 277 & 86.21 & 44.91 & 109.0 & & 0.9321 \\
\hline 298 & 134.0 & 66.79 & 184.4 & & 0.8759 \\
\hline 318 & 139.3 & 25.51 & 144.6 & & 0.9285 \\
\hline 338 & 144.1 & 58.50 & 108.6 & & 0.7848 \\
\hline \multicolumn{6}{|c|}{ Pseudo Second Order Kinetic Model } \\
\hline $\begin{array}{c}\text { Temperature } \\
\text { (K) }\end{array}$ & $\begin{array}{c}\mathrm{h} \\
((\mathrm{g} / \mathrm{mg}) / \mathrm{min})\end{array}$ & $\begin{array}{c}\mathrm{k}_{2} \times 10^{-3} \\
(\mathrm{~g} / \mathrm{mg} \cdot \mathrm{min})\end{array}$ & $\begin{array}{c}Q_{e} \\
(\mathrm{mg} / \mathrm{g})\end{array}$ & & $\mathrm{R}^{2}$ \\
\hline 277 & 86.21 & 3.460 & 107.5 & & 0.9900 \\
\hline 298 & 134.0 & 3.726 & 151.5 & & 0.9920 \\
\hline 318 & 139.3 & 4.019 & 158.0 & & 0.9929 \\
\hline 338 & 144.1 & 5.423 & 158.2 & & 0.9943 \\
\hline \multicolumn{6}{|c|}{ Intraparticle Diffusion Model } \\
\hline $\begin{array}{c}\text { Temperature } \\
\text { (K) }\end{array}$ & \multicolumn{2}{|c|}{$\frac{k_{i}}{(g / m g \cdot m i n 0.5)}$} & \multicolumn{3}{|c|}{$\mathrm{R}^{2}$} \\
\hline 277 & \multicolumn{2}{|c|}{6.950} & \multicolumn{3}{|c|}{0.8642} \\
\hline 298 & \multicolumn{2}{|c|}{9.472} & \multicolumn{3}{|c|}{0.7675} \\
\hline 318 & \multicolumn{2}{|c|}{9.431} & \multicolumn{3}{|c|}{0.7924} \\
\hline 338 & \multicolumn{2}{|c|}{8.736} & \multicolumn{3}{|c|}{0.7752} \\
\hline \multicolumn{6}{|c|}{ Ritchie's Second Order Kinetic Model } \\
\hline $\begin{array}{c}\text { Temperature } \\
(\mathrm{K})\end{array}$ & $\begin{array}{l}k_{R} \times 10^{3} \\
(1 / \min )\end{array}$ & $\begin{array}{c}Q_{e} \\
(m g / g)\end{array}$ & & $\mathrm{R}^{2}$ & \\
\hline 277 & 37.30 & 104.2 & & 0.9874 & \\
\hline 298 & 48.40 & 153.8 & & 0.9546 & \\
\hline 318 & 78.75 & 158.7 & & 0.9679 & \\
\hline 338 & 65.48 & 151.5 & & 0.9466 & \\
\hline
\end{tabular}

The correlation coefficients for the linear plots of kinetic models demonstrates poor correlation of the pseudo-first kinetic model and intraparticle diffusion models compare to pseudo-second order kinetic model for m-p(EG-VPN) microspheres. Consequently, $\mathrm{Cu}(\mathrm{II})$ adsorption onto produced adsorbents followed pseudo-second order kinetic model. Several studies have also been stated in the literature that $\mathrm{Cu}(\mathrm{II})$ adsorption onto polymeric or magnetic adsorbents followed pseudo-second order kinetic model. [26-36]

\section{CONCLUSION}

In this present study, adsorption properties of a new magnetic chelating polymer adsorbent $m-p(E G-V P N)$ microspheres were investigated in order to use $\mathrm{Cu}$ (II) ion removal from aqueous media. According to kinetic studies, the adsorption process could be best described by the pseudo-second order kinetic model. Isothermal studies demonstrated that all the isotherm data can be fitted with Langmuir isotherm model. The total adsorption capacity of $m-p(E G-V P N)$ 
microspheres was $270.3 \mathrm{mg}$ per gram adsorbent. If the magnetic features, adsorption capacity and their reusability were taken into consideration, $m-p(E G-V P N)$ microspheres have a potential applicability for $\mathrm{Cu}(\mathrm{II})$ removal in industrial waste water treatment.

\section{References}

1. N. Pekel, O. Güven, Separation of heavy metal ıons by complexation on poly (n-vinyl imidazole) hydrogels, Polym. Bull., 51 (2004) 307-314.

2. A. Denizli, K. Kesenci, Y. Arıca, E. Pişkin, Dithiocarbamate-incorporated monosize polystyrene microspheres for selective removal of mercury ions, React. Funct. Polym., 44 (2000) 235-243.

3. A. Kara, Adsorption of $\mathrm{Cr}(\mathrm{VI})$ ions onto poly(ethylene glycol dimethacrylate-1-vinyl-1,2,4-triazole), J. Appl. Polym. Sci., 114 (2009) 948-955.

4. H.B. Bradl, Heavy metals in the environment: Origin, interaction and remediation., Editor: Bradl, H.B. Elsevier Academic Press, UK, 2004.

5. A. Kara, E. Demirbel, Physicochemical parameters of $\mathrm{Cu}(\mathrm{II})$ ions adsorption from aqueous solution by magnetic-poly(divnylbenzene-n-vinylimidazole) microbeads, Sep. Sci. Technol., 47 (2012) 709-722.

6. F. Iemma, G. Cirillo, U.G. Spizzirri, F. Puoci, O.I. Parisi, N. Picci, Removal of metal ions from aqueous solution by chelating polymeric microspheres bearing phytic acid derivatives, Eur. Polym. J., 44 (2008) 1183-1190.

7. A. Tiwari, P. Kathane, Adsorption of $\mathrm{Cu}^{2+}$ ions onto polyvinyl alcohol-alginate bound nano magnetite microspheres: a kinetic and thermodynamic study, Int. Research J. Environment. Sci., 4 (2015) 12-21.

8. P.K. Roy, V. Swami, D. Kumar, C. Rajagopal, Removal of toxic metals using superabsorbent polyelectrolytic hydrogels, J. Appl. Polym. Sci., 122 (2011) 2415-2423.

9. T. Trakulsujaritchok, N. Noiphom, N. Tangtreamjitmun R. Saeeng, Adsorptive features of poly(glycidyl methacrylate hydroxyethyl methacrylate): effect of porogen formulation on heavy metal ion adsorption, J. Mater. Sci., 46 (2011) 5350-5362.

10. D. Duranoğlu, A.W. Trochimczuk, Ü. Beker, A comparison study of peach stone and acrylonitriledivinylbenzene copolymer based activated carbons as chromium(VI) sorbents, Chem. Eng. J., (2010) 5663.

11. B. Salih, A. Denizli, B. Engin, A. Tuncel, E. Piskin, Congo red attached poly(EGDMA-HEMA) microspheres as specific sorbents for removal of cadmium ions, J. Appl. Polym. Sci., 60 (1996) 871-877.

12. Y. Gursel, E. Yavuz, G. Gokay, B.F. Şenkal, Preparation of the sulfonamide containing block copolymer as polymeric sorbent for removal of mercury from aqueous solutions, Sep. Sci. Technol., 45 (2010) 2406-2412.

13. I. Langmuir, The constitution and fundemental properties of solids and liquids. Part I. Solids, J. Am. Chem. Soc., 38 (1916) 2221-2295.
14. A. Kara, B. Acemioğlu, M.H. Alma, M. Cebe, Adsorption of $\mathrm{Cr}(\mathrm{II}), \mathrm{Ni}(\mathrm{II}), \mathrm{Zn}(\mathrm{II}), \mathrm{Co}(\mathrm{II})$ ions onto phenolated wood resin, J. Appl. Polym. Sci., 101 (2006) 2838-2846.

15. R. Laus, T.G. Costa, B. Szpoganicz, V.T. Fávere, Adsorption and desorption of $\mathrm{Cu}(\mathrm{II}), \mathrm{Cd}(\mathrm{II})$ and $\mathrm{Pb}(\mathrm{II})$ ions using chitosan crosslinked with epichlorohydrintriphosphate as the adsorbent, J. Hazard. Mater., 183 (2010) 233-241.

16. S.S. Tripathy, A.M. Raichur, Abatement of fluoride from water using manganese dioxidecoated activated alumina, J. Hazard. Mater., 153 (2008) 1043-1051.

17. C. Namasivayam, D. Kavita, Removal of congo red from water by adsorption on to activated carbon prepared from coir pith, an agricultural solid waste, Dyes and Pigments, 54 (2002) 47-58.

18. A. Özcan, A.S. Özcan, S. Tunali, T. Akar, I. Kiran, Determination of the equilibrium, kinetic and thermodynamic parameters of adsorption of copper(II) ions onto seeds of capsicum annuum, J. Hazard. Mater., 124 (2005) 200-208.

19. N. Ünlü, M. Ersoz, Adsorption characteristics of heavy metal ions onto a low cost biopolymeric sorbent from aqueous solutions, J. Hazard. Mater., 136 (2006) 272280.

20. A. Tassist, H. Lounici, N. Abdi, N. Mameri, Equilibrium, kinetic and thermodynamic studies on aluminum biosorption by a mycelial biomass (Streptomyces rimosus), J. Hazard. Mater., 183 (2010) 35-43.

21. A. Kara, E. Demirbel, Kinetic, isotherm and thermodynamic analysis on adsorption of $\mathrm{Cr}(\mathrm{VI})$ ions from aqueous solutions by synthesis and characterization of magnetic-poly(divinylbenzenevinylimidazole) microbeads, Water Air Soil Pollut., 223 (2012) 2387-2403.

22. S. Lagergren, Zur theorie der sogenannten Adsorption gel oster stoffe. Kungliga Svenska Vetenskapsakademiens" Handlingar, 25 (1898) 1-39.

23. Y.S. Ho, G. McKay, Pseudo-second-order model for sorption processes, Process Biochem., 34 (1999) 451-465.

24. A.G. Ritchie, Alternative to elovich equation for kinetics of adsorption of gases on solids, J. Chem. Soc. Faraday Transact., 73 (1977) 1650-1653.

25. B. Osman, E.T. Özer, A. Kara, Ş. Güçer, N. Beşirli, Assesment of dimethyl phthalate removal from aqueous phase using barium hexaferrite containing magnetic beads, J. Colloid. Interface Sci., 378 (2012) 167-174.

26. E. Büyüktuncel, S. Bektaş, Ö. Genç., A. Denizli, Poly(vinylalcohol) coated/Cibacron Blue F3GAattached polypropylene hollow fiber membranes for removal of cadmium ions from aquatic systems, React. Funct. Polym., 47 (2001) 1-10.

27. A. Denizli, S. Şenel, G. Alsancak, N. Tüzmen, R. Say, Mercury removal from synthetic solutions using poly(2-hydroxyethylmethacrylate) gel beads modified with poly(ethyleneimine), React. Funct. Polym., 55 (2003) 121-130.

28. Ö. Genç, L. Soysal, G. Bayramoğlu, M.Y. Arıca, S. Bektaş, Procion Green H-4G immobilized poly(hydroxyethylmethacrylate/chitosan) composite membranes for heavy metal removal, J. Hazard. Mater., 97 (2003) 111-125. 
29. A. Kara, L. Uzun, N. Beşirli, A. Denizli, Poly(ethylene glycol dimetachrylate-n-vinyl imidazole) beads for heavy metal removal. J. Hazard. Mater., 106 (2004) 93-99.

30. A. Denizli, S. Bektaş, M.Y. Arıca, Ö. Genç, Metalchelating properties of poly(2-hydroxy ethyl methacrylate methacryloyl amido histidine) membranes, J. Appl. Polym. Sci., 97 (2005) 1213-1219.

31. S. Malcı, C. Kavaklı, A. Tuncel, B. Salih, Selective adsorption, pre-concentration and matrix elimination for the determination of $\mathrm{Pb}(\mathrm{II}), \mathrm{Cd}(\mathrm{II}), \mathrm{Hg}(\mathrm{II})$ and $\mathrm{Cr}$ (III) using 1,5,9,13-tetrathiacyclohexadecane3,11-diol anchored poly(p-chloromethylstyreneethyleneglycoldimethacrylate) microbeads, J. Anal. Chim. Acta, 550 (2005) 24-32.

32. S. Şenel, A. Kara, A. Karabakan, A. Denizli, Alanine containing porous beads for mercury removal from artificial solutions, J. Appl. Polym. Sci., 100 (2006) 1222-1228.
33. G. Bayramoğlu, M. Y. Arıca, S. Bektaş, Removal of $\mathrm{Cd}(\mathrm{II}), \mathrm{Hg}(\mathrm{II})$, and $\mathrm{Pb}(\mathrm{II})$ ions from aqueous solution using $\mathrm{p}$ (hema/chitosan) membranes, J. Appl. Polym. Sci., 106 (2007) 169-177.

34. L. Uzun, D. Türkmen, E. Yılmaz, S. Bektaş, A. Denizli, Cysteine functionalized poly(hydroxyethyl methacrylate) monolith for heavy metal removal, Colloids Surf. A, 330 (2008) 161-167.

35. X.G. Li, X.L. Ma, J. Sun, M.R. Huang, Powerful reactive sorption of silver(I) and mercury(II) onto poly(ophenylenediamine) microparticles, Langmuir, 25 (2009) 1675-1684.

36. D. Türkmen, E. Yılmaz, N. Öztürk, S. Akgöl, A. Denizli, Poly(hydroxyethyl methacrylate) nanobeads containing imidazole groups for removal of $\mathrm{Cu}(\mathrm{II})$ ions, Mater. Sci. Eng. C, 29 (2009) 2072-2078. 